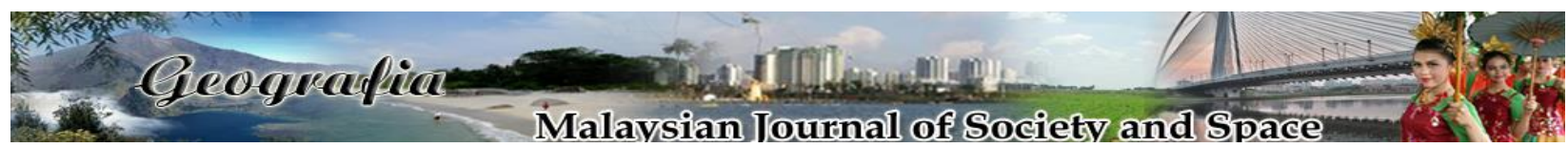

\title{
Persaingan PRU ke-14 di Pahang: Pengekalan status quo melalui pertembungan tiga penjuru
}

\author{
Muhamad Nadzri Mohamed Noor \\ Program Sains Politik, Fakulti Sains Sosial dan Kemanusiaan, \\ Universiti Kebangsaan Malaysia
}

Correspondence: Muhamad Nadzri Mohamed Noor (email: nadzri@ukm.edu.my)

Received: 20 June 2019; Accepted: 01 October 2019; Published: 25 November 2019

\begin{abstract}
Abstrak
Strategi memecahkan undi pihak pembangkang oleh pihak penyandang Barisan Nasional (BN) dalam Pilihan Raya Umum ke-14 (PRU 14) bukan lagi satu misteri. Matlamat penyandang adalah untuk memenangi kawasan legislatif sebanyak yang mungkin, sekurang-kurangnya secara pluraliti. Strategi ini walau bagaimanapun tidak menjadi di kesemua negeri di Semenanjung kecuali di Perlis dan Pahang. Objektif artikel ini, untuk itu adalah untuk menganalisis kedinamikan persaingan tiga penjuru dan hubungkaitnya dengan faktor kewilayahan dalam PRU 2018 di Pahang. Artikel ini juga mengenal pasti beberapa implikasi sistem pilihan raya pelbagai parti di negeri itu. Berdasarkan kaedah pemerhatian langsung dan laporan media, artikel ini menghujahkan, meskipun strategi pertembungan tiga penjuru telah mengekalkan status quo di Pahang, tetapi corak pengundian yang menolak BN di negeri itu adalah hampir sama di negerinegeri lain di Semenanjung. Hal ini menperjelaskan mengapa kerusi BN di Pahang khasnya kerusi Dewan Undangan Negeri (DUN) di Pahang semakin berkurangan dengan ketara di dalam PRU 14, dan pihak pencabar hanya kekurangan beberapa kerusi sahaja untuk menafikan majoriti $\mathrm{BN}$. Malah persaingan tiga penjuru telah mengelakkan BN daripada kalah dengan lebih teruk di peringkat parlimen disamping mempertahankan kedudukannya sebagai kerajaan negeri di Pahang. Artikel ini berharap untuk menambah korpus ilmu secara khusus di dalam politik pilihan raya Pahang dan perspektif regionalisme dalam memahami politik Malaysia secara amnya.
\end{abstract}

Kata kunci: Barisan Nasional, Pakatan Harapan, PRU ke-14 Pahang, persaingan tiga penjuru, regionalism 


\title{
The 14th General Election in Pahang: Maintaining status quo through three- cornered fights
}

\begin{abstract}
The strategy in splitting the opposition's votes utilized by the then ruling party in Malaysia, the Barisan Nasional (BN) in the 14th General Election (GE 14) is no longer a mistery. The objective was to win the elections, both at the federal and state level, at least based on plurality. In the Peninsular, almost all of the constituencies were contested with three-cornered fights. This stategy, however, turned out badly for BN except in Perlis and Pahang. The objective of this paper is to analyse the dynamics of the three-cornered fights and its relationship with regionalisme in Pahang in GE 2018. Based on direct observation and media reporting, this article argues that, although the strategy for the three-cornered competition has enabled $\mathrm{BN}$ to sustain its status quo in Pahang, but voting trend in Pahang was almost similar to the other states in the Peninsular. This explains why the number of the legislative seats won by BN, particularly at the state assembly of Pahang, have decreased significantly. In fact, the opposition lack only few seats to deny BN's simple majority in Pahang. The three-cornered contest, thus, have avoided $\mathrm{BN}$ from suffering a bigger losses. This paper hopes to contribute to the academic corpus particularly on elections in Pahang and regionalism perspective in Malaysia politics in general.
\end{abstract}

Keywords: Barisan Nasional, GE 14 in Pahang, Pakatan Harapan, three-cornered contest, regionalism

\section{Pengenalan}

Strategi memecahkan undi, melalui pemisahan pihak lawan adalah modus operandi yang paling ketara dalam "menu manipulasi" pentadbiran Najib dalam Pilihan Raya Umum ke-14 (PRU 14) (Shedler, 2002). Pertamanya, pihak penyandang Barisan Nasional (BN) melakukan kerjasama secara longgar bersama Parti Islam SeMalaysia (PAS). Melalui beberapa sokongan dasar seperti pembentangan Rang Undang-undang 355 (Akta Mahkamah Syariah) dan tajaan politik, BN berjaya menjarakkan PAS dari gabungan pihak pembangkang yang baharu, Pakatan Harapan (PH). Kedua, cubaan PH untuk mendaftarkan gabungan mereka telah dinafikan oleh Pendaftar Pertubuhan (RoS). Ini menyebabkan hal yang ketiga, iaitu penggunaan logo PH di dalam PRU 14 dinafikan oleh pihak Suruhanjaya Pilihan Raya (SPR). Keempat, persempadanan kawasan pilihan raya diwartakan oleh pentadbiran Najib kira-kira sebulan sebelum PRU 14, dan sempadan itu pula menurut Pengerusi SPR dilakukan berdasarkan garis etnik. Kelima dan yang terakhir, parti Melayu baharu yang ditubuhkan oleh bekas Perdana Menteri Mahathir Mohamad dan Muhyiddin Yassin - Parti Peribumi Bersatu Malaysia (Bersatu), telah diharamkan secara sementara oleh RoS hanya beberapa hari sebelum PRU 14 bermula.

Strategi-strategi ini membolehkan populariti pembangkang diimbangi oleh parti penyandang. Perpecahan pembangkang ini menstrukturkan pesaingan tiga penjuru hampir di kesemua kawasan di Semenanjung. Dalam Pilihan Raya Kecil (PRK) Kuala Kangsar dan Sungai Besar serta Pilihan Raya Negeri (PRN) Sarawak pada 2016, BN telah mendapat kemenangan yang besar. Keputusan itu dicapai bukanlah kerana populariti BN bertambah baik, sebagai mana yang 
disangka oleh pentadbiran Najib, tetapi kerana keadaan pembangkang yang tidak tersusun dan berpecah-pecah. Sebahagiannya disebabkan oleh pertembungan tiga penjuru dalam kesemua pilihan raya itu. Penafian pendaftaran dan penggunaan logo $\mathrm{PH}$ secara bersama pula bertujuan untuk membangkitkan prasangka di kalangan pengundi dan calon pembangkang, memecahkan dan menakut-nakutkan mereka. Berdasarkan corak pengundian di masa lepas, penggunaan logo DAP boleh menolak (demotivate) pengundi Melayu dari mengundi parti itu. Logo PAS pula boleh menjauhkan sokongan pengundi Cina. Pengharaman parti Bersatu pula, yang telah diletakkan PH untuk merebut separuh kerusi UMNO/BN di Semenanjung pula secara simboliknya menafikan pertembungan dua parti nasionalis Melayu, sekaligus meletakkan imej UMNO sebagai satu-satunya parti nasionalis Melayu dalam PRU 14. Hal ini adalah penting dalam perekayasaan kemenangan UMNO/BN yang sangat bergantung kepada undi Melayu dalam mempertahankan status quo dalam PRU 14 (Muhamad Nadzri \& Jamaie, 2018).

Dengan 70 peratus etnik Melayu dari keseluruhan populasi di Pahang (Department of Information, 2015), persaingan plihan raya di negeri ini merupakan pertembungan yang penting, kedua-duanya bagi pihak penyandang dan pencabar. Bagi pihak penyandang, negeri Pahang yang menjadi salah satu kubu kuat BN sejak 1955, perlu dipertahankan dalam membantu kedudukan mereka di persekutuan. Kegagalan mempertahankan kerusi majoriti Melayu/Bumiputera, bermakna mereka berisiko untuk hilang kedudukan di persekutuan dan juga di peringkat negeri. Untuk pihak pencabar pula, khasnya PH, satu-satunya halangan untuk ke Putrajaya dan beberapa negeri di Malaysia adalah adalah keupayaan mereka untuk menguasai kerusi majoriti Melayu/Bumiputera. Oleh itu, adalah menjadi tujuan penulisan artikel ini untuk menganalisis kedinamikan persaingan tiga penjuru dan hubungannya dengan faktor kewilayahan dalam PRU 2018 di Pahang. Artikel ini juga mengenal pasti beberapa implikasi sistem pilihan raya pelbagai parti di negeri itu.

\section{Kerangka Teoritikal: Perubahan regim dan perilaku pengundi}

Di dalam korpus ilmu perubahan regim dan pendemokrasian, terdapat dua teori utama yang menjelaskan mengapa transisi politik berlaku. Pertama adalah teori pecahan dan kedua adalah teori penyusunan/penyatuan pembangkang. Antara andaian asas di dalam teori pecahan elit adalah, kekuatan rejim autoritarian terletak kepada kesepaduan elit di dalam mempertahan kestabilan pemerintah (Brownlee, 2007: 123). Ancaman utama kepada kestabilan itu hanya wujud di kalangan elit negara dan jika ada pecahan maka kestabilan itu boleh tergugat serta membuka ruang kepada perubahan rejim (Compton, 2000: 60).

Teori kedua pula mengandaikan perubahan rejim autoritarian hanya boleh berlaku apabila pasukan oposisi disusun dengan lebih menyeluruh dalam memberi cabaran yang kompetitif kepada pihak penyandang. Sistem autoritarian memberi kekuatan struktural kepada parti penyandang, dan kelebihan ini sering digunakan untuk memanipulasi sistem politik dan melemahkan pembangkang (López, 2002). Dengan kekuatan yang ada kepada parti penyandang, barisan pembangkang yang berpecah akan mengalami kesukaran untuk memenangi pilihan raya terutamanya jika sistem majoritarian atau first-pass-the-post digunapakai

Di dalam memahami tingkah laku pengundi pula, terdapat tiga model utama yang popular. Sekolah pemikiran Columbia melalui karya utama mereka "Voting: The People's Choice" menekankan faktor sosiologikal dalam memerihalkan tingkahlaku pengundi (Lazarsfeld, Berelson \& Gaudet, 1944). Model ini menghubungkaitkan latar belakang kumpulan seseorang 
individu atau kelompok pengundi, seperti agama, tempat kerja dan jaringan sosial dengan perilaku pengundian mereka.

Sekolah pemikiran Michigan pula dengan karya mereka, "The American Voter" mula mendapat tempat di dalam kajian perilaku pengundian sejak 1960an (Campbell et. al., 1960). Model ini menganjurkan idea bahawa seseorang itu melakukan pengundian berdasarkan ikatan psikologikal mereka dengan sesebuah parti. Dengan erti kata lain, mereka mengidentifikasi diri mereka dengan parti tertentu. Ikatan psikologikal itu dipupuk oleh proses sosial yang agak lama melalui tiga ciri-ciri iaitu sosiologikal (etnisiti, agama dan gender), status sosial (kelas sosial dan pekerjaan) dan keibubapaan (nilai hidup dan partisan).

Sebaliknya, model Rochester yang berasaskan teori pilihan rasional dibangunkan pada 1980an. Dalam "Restropective Voting in American National Elections", Fiorina (1981) mendapati pengundi melakukan pengundian secara rasional dengan mengundi parti penyandang yang memenuhi kepentingan mereka dan menghukum parti yang sebaliknya. Model ini juga menekankan pengaruh kempen yang efektif dalam membantu mempengaruhi pengundi.

Ketiga-tiga model ini didirikan daripada amalan pengundian di Amerika Syarikat. Kesemuanya secara individu mungkin tidak sepenuhnya bersesuaian dengan konteks Malaysia. Ini berikutan terdapat ketaksamaan yang ketara di antara sistem, masyarakat, struktur, proses dan nilai di antara politik dan masyarakat Amerika dan Malaysia. Sebaliknya, penggunaan model ini untuk memahami perilaku pengundi di Malaysia perlu diimbangi dengan aplikasi konsep yang dibina di Asia atau di dunia membangun bagi melahirkan analisis yang lebih reflektif. Antaranya konsep penaung-dinaung (clientelism), kebengantungan (dependency), komuniti bayangan (imagined communities), negara idaman (nations-of-intent) dan senjata orang-orang lemah (weapons of the weak).

Untuk itu perbincangan perilaku pengundi dalam PRU 14 di Pahang akan menggunapakai ketiga-tiga model ini secara eklektik dengan membahagikan kawasan-kawasan pilihan raya berdasarkan dinamik regionalisme di negeri Pahang sebelum menghubungkaitkannya secara dinamik dengan keputusan pengundian dan konsep sains sosial di dunia membangun.

\section{Situasi politik menjelang PRU ke-14 di Malaysia dan Negeri Pahang}

Situasi politik Malaysia sejak Najib menjawat kedudukan sebagai Perdana Menteri Malaysia yang keenam pada April 2009 adalah cukup kompetitif dari sudut persaingan pilihan raya. Meskipun pelbagai manipulasi dilaksanakan oleh pentadbiran $\mathrm{BN}$, namun atas beberapa faktor penting seperti kewujudan isu yang berimpak, kewujudan gabungan pembangkang yang bersatu, dan perkembangan ruang sivil melalui teknologi komunikasi dan internet, populariti BN kian menurun. Meskipun pentadbiran Najib berjaya mempertahankan kedudukan dalam PRU 13, namun majoriti BN di parlimen berkurangan dan BN juga buat pertama kalinya tewas dari sudut undi popular buat pertama kalinya sejak 1969. Dasar-dasar populisme-ekonomi melalui program-program bantuan kerajaan banyak membantu pentadbiran Najib dalam mempertahankan status quo dalam pilihan raya itu.

Namun di sebalik kejayaan itu, Najib dilihat kecewa dengan keputusan PRU 13. Pengundi Cina menjadi sasaran kritikan pentadbiran Najib. Program bantuan kewangan kerajaan kepada rakyat pula, dengan fokus untuk memenangi hati dan minda pengundi dalam PRU 13 telah meletakkan keadaan kewangan negara dalam keadaan yang tertekan sehinggakan sistem percukaian baharu diperkenalkan iaitu Cukai Barangan dan Perkhidmatan (GST). Dalam masa 
yang sama, subsidi-subsidi barangan pengguna dari gula sehingga ke petroleum, dihapuskan oleh pentadbiran Najib. Pada penghujung 2014 pula, ketua pembangkang Anwar Ibrahim dan media antarabangsa mendedahkan skandal kewangan pentadbiran Najib, iaitu penyalahgunaan syarikat pelaburan negara $1 \mathrm{MDB}$ yang ditubuhkan Najib untuk kepentingan peribadi Najib dan parti pemerintah. Skandal ini telah digunakan oleh Mahathir untuk mengkritik pentadbiran Najib secara terbuka dan Najib membalas tindakan itu dengan agresif. Sikap defensif Najib dalam menguruskan isu 1MDB dan agresif dalam berhadapan dengan Mahathir telah menyebabkan berlaku keretakan dalam kesepaduan elit di dalam parti pemerintah dan kerajaan. Akhirnya bermula pada Julai 2015, Najib secara melulu melakukan penyisihan pemimpin di dalam UMNO, kabinetnya dan kerajaan dengan memecat beberapa penjawat tertinggi di dalam parti pemerintah dan institusi negara.

Pihak pembangkang pula mula menyusun organisasi mereka secara pragmatik dengan menubuhkan pakatan baharu (PH) sebagai langkah awal. Kemudian beberapa parti baru ditubuhkan dalam menyaingi UMNO dan PAS. Ini termasuk Bersatu, Parti Amanah Negara (Amanah) dan Parti Warisan Sabah (Warisan). Yang paling mengejutkan adalah, Mahathir dinamakan sebagai pengerusi PH pada 2017 dan pada awal 2018 dinamakan sebagai calon perdana menteri PH. Hal ini membawa kepada kepada beberapa faktor penting. Pertama, $\mathrm{PH}$ mengunapakai perpecahan elit pemerintah sepenuhnya dengan penubuhaan Bersatu dan Warisan serta memberi peranan penting kepada Mahathir untuk menumbangkan Najib. Kedua, parti-parti ini pula dijangka akan melaksanakan penerombosan (breakthrough) bagi pihak pembangkang yang selama ini sukar untuk dilakukan. Ketiga, penyusunan semula gabungan pembangkang yang paling pragmatik dalam politik Malaysia setakat ini, membolehkan pakatan itu lebih melebar, representatif dan berwibawa kerana bukan sahaja melibatkan parti yang pelbagai tetapi tokoh yang ternama temasuk Mahathir, Wan Azizah Wan Ismail, Lim Kit Siang, Muhyiddin, Shafie Apdal, Mohamad Sabu, Lim Guan Eng, Azmin Ali dan Mukriz Mahathir (Muhamad Nadzri, 2018).

Isu yang menjadi fokus utama $\mathrm{PH}$ adalah bagaimana situasi ekonomi yang menekan rakyat dan negara berkait rapat dengan penyelewengan di dalam pentadbiran Najib. Untuk itu isu berkaitan dengan korupsi 1MDB seperti kemasukkan duit RM2.6 bilion ke dalam akaun peribadi Najib, dan kemewahan kehidupan keluarga Najib, serta kenaikan kos sara hidup disebabkan oleh dasar kerajaan seperti pengenalan GST, penghapusan subsidi dan pengenaan tol di lebuhraya dibangkitkan dari masa ke semasa hampir di semua ceramah $\mathrm{PH}$ yang dilakukan secara maya atau di ruang umum di seluruh negara. Negara dibayangkan oleh Mahathir dan $\mathrm{PH}$ sebagai berada di dalam krisis kerana ditadbir oleh kerajaan kleptokrat.

Salah satu ciri umum PRU 14 di Semenanjung, isu nasional nampaknya membayangi isu negeri dan tempatan. Hal ini turut terpakai di negeri Pahang. Meskipun mengalami beberapa permasalahan sosioekonomi, isu-isu yang ketara di kalangan umum di Pahang adalah melibatkan isu nasional. Proses penyah-industrian (deindustrialisation) memberi kesan besar untuk negeri itu. Ramai yang kehilangan kerja dan terpaksa bermigrasi ke bandar-bandar besar. Industri yang tinggal pula umumnya melibatkan kadar upah buruh yang kecil, ia bukan sahaja menyebabkan kesukaran rakyat Pahang untuk menghadapai tekanan kenaikan kos sara hidup, tetapi juga melibatkan kemasukan buruh luar ke negeri itu dengan agak signifikan. Dasar ekonomi Najib juga, sebagaimana pada zaman pentadbiran Mahathir dahulu (1981-2003), banyak berkitar dengan projek-projek mega khasnya di Lembah Kelang. Hal ini menyebabkan kadar pembangunan yang tidak seimbang berlaku secara di Malaysia, termasuk di Pahang yang merupakan antara negeri termundur di Semenanjung. 
Namun kemunduran dan ketidakadilan ekonomi ini, dalam konteks persaingan pilihan raya dalam PRU 14 di Pahang, membawa kesan yang bercampur-campur. Dari satu dimensi, ia menyebabkan rakyat Pahang, khasnya orang Melayu sangat bergantung dengan bantuan pemimpin mereka khasnya di kawasan luar bandar. Sebaliknya di kawasan-kawasan bandar yang lebih moden (modernised), kemunduran dan ketidakadilan itu memungkin penolakan dan persoalan dibangkitkan oleh penduduk setempat. Mereka merasai tekanan kenaikan kos sara hidup yang lebih ketara berbanding mereka di kawasan luar bandar di Pahang. Meskipun mereka mempunyai kedudukan sosio-ekonomi yang lebih baik kerana lebih terdedah dengan pelbagai industri moden dan akses-akses penting seperti pendidikan dan teknologi, penduduk di kawasan bandar dan pinggiran bansar di Pahang adalah lebih kritikal terhadap parti pemerintah, progresif dan strategik dalam pembuangan undi. Malah banyak isu-isu negeri atau lokal dibangkitkan di kawasan ini berbanding di kawasan luar bandar di Pahang. Di bandar Bentong umpamanya, isu pengoperasian bahan berbahaya oleh Syarikat Lynas adalah isu utama. Malah calon PH di Parlimen itu, Wong Tack, adalah tokoh aktivis anti-Lynas dan anak tempatan yang terkenal. Di Kuantan pula, selain isu Lynas, isu kerosakan alam sekitar disebabkan aktiviti perlombongan bauxite yang tidak terurus merupakan isu penting. Di kawasan bandar Raub pula, isu pembalakan dan perlombongan emas adalah isu utama. Namun di sebalik isu-isu ini, kesemuanya hampir tenggelam jika dibandingkan dengan isu nasional yang dibawa oleh pembangkang dalam PRU 14, khasnya isu kos sara hidup dan salahtadbir pentadbiran Najib. Situasi politik di Pahang pada pra-PRU 2018 adalah tidak kondusif kepada parti pemerintah dan BN nampaknya perlu mengharap sokongan pengundi Melayu serta keberkesanan strategi memecahkan undi lawan untuk mengekalkan kedudukan di Pahang.

Oleh yang demikian, konteks persaingan PRU 14 di Pahang yang melibatkan 825,636 pengundi berdaftar dengan 70 peratus Melayu, hampir 15 peratus Cina dan 4 peratus etnik India (Abdul Razak, 2018), corak pengundian boleh difahami secara bermakna berdasarkan pecahan demografi (etnisiti) dan tahap pembangunan (bandar, pinggiran dan luar bandar) kawasankawasan pilihan rayanya.

\section{Pola pengundian di peringkat Parlimen PRU 14 Pahang}

Berbanding PRU 13, keputusan PRU 14 di peringkat kerusi parlimen di Pahang mencatatkan satu penambahan kerusi parlimen bagi pihak pembangkang, iaitu dari empat kepada lima kerusi parlimen dari keseluruhan empat belas kawasan. Di peringkat Dewan Undangan Negeri (DUN) pula, pembangkang mencatatkan penambahan kerusi yang lebih ketara, iaitu dari 12 kerusi (PRU 13) kepada 17 (PRU 14). Hal ini adalah kebalikan dari hasil yang diharapkan oleh strategi rejim pemerintah. Perlawanan tiga penjuru sepatutnya, dari sudut perpecahan pembangkang akan melahirkan keputusan yang lebih positif kepada pihak penyandang. Namun di kebanyakan negeri di Semenanjung Malaysia, keadaan sebaliknya berlaku yang menyebabkan BN kehilangan kedudukan di persekutuan dan banyak kerajaan negeri. Meskipun BN masih mendapat majoriti di peringkat Parlimen dan DUN Pahang, berbeza di kesemua negeri lain di Semenanjung kecuali Perlis di mana BN kehilangan majoriti, populariti dan kerusi BN di Pahang mencatat penurunan yang signifikan.

Dalam memahami fenomena ini, kesan persaingan tiga penjuru dalam PRU 14 boleh ditelusuri melalui dinamik kewilayahan (Ostwald et al., 2018). Di dalam dinamika ini, komposisi etnik, tahap pembangunan dan faktor lokal adalah berbeza-beza. Ia membuatkan parti-parti yang bertanding juga, mempunyai pengaruh yang berbeza di kawasan yang berlainan. 
Kawasan-kawasan pilihan raya di Pahang boleh dibahagikan mengikut tahap pembangunan dan komposisi etnik. Dari 14 kerusi Parlimen sebagaimana di Jadual 1, tiga kategori kawasan boleh digariskan berdasar tahap pembangunan, iaitu kawasan bandar (B), pinggiran bandar (PB) dan luar bandar (LB). Apabila dipadankan dengan komposisi etnik pula, kawasan bandar dan pinggiran bandar adalah kawasan campuran dengan jumlah pengundi Melayu tidak begitu dominan dengan majoriti tidak lebih 75 peratus. Ini berbeza dengan kawasan parlimen luar bandar di Pahang di mana kesemua kawasan itu adalah kawasan supra-majoriti Melayu, kecuali Cameron Highlands dan Bera, dengan komposisi pengundi Melayu melebihi 75 peratus.

Di peringkat parlimen Pahang, $\mathrm{PH}$ mendominasi kawasan bandar dan pinggiran bandar iaitu Kuantan (B), Indera Mahkota (B), Raub (PB), Temerloh (PB) dan Bentong (PB). Kesemua kerusi $\mathrm{PH}$ dimenangi di kawasan-kawasan ini dan $\mathrm{BN}$ hanya berupaya memenangi dua kawasan pinggiran bandar (Pekan (PB) dan Paya Besar (PB)). Sebaliknya, BN menguasai kesemua tujuh kerusi luar bandar di Pahang termasuk satu kawasan etnik campuran di Cameron Highlands.

Apabila keputusan ini dan faktor lokaliti di atas disilangsemak dengan komposisi etnisiti setiap kawasan parlimen di Pahang, didapati terdapat korelasi yang tinggi. Kemenangan PH di peringkat parlimen di Pahang disumbangkan di kawasan bercampur dan di kerusi majoriti Melayu yang rendah, kesemuanya berada di dalam kategori kawasan bandar dan pinggiran bandar. Kemenangan BN di sembilan kerusi parlimen Pahang dari sudut etnisiti pula, kesemuanya - kecuali parlimen Bera dan Cameron Highlands, dicapai di kawasan supra-majoriti Melayu.

Dari sudut pertautan etnisiti, lokaliti dan pilihan raya pula, kebanyakan etnik Cina bandar mula memberi sokongan yang kuat kepada pembangkang sejak PRU 12 (2008). Di kalangan pengundi Melayu dan India di kawasan bandar dan pinggiran bandar pula, sesetengah mereka juga didapati mula sokongan kepada pembangkang sejak PRU 12 meskipun tidak setinggi etnik Cina. Hal ini terpakai dengan pola pengundian di kawasan bandar dan pinggiran bandar kerusi parlimen negeri Pahang. Kehidupan di bandar dan pinggiran bandar membolehkan masyarakat industri di kawasan itu mendapat lebih akses kepada kemajuan, termasuk dalam ekonomi, pendidikan dan teknologi. Ia mewujudkan kelas menengah dan kelas pekerja yang besar dengan dinamik yang berbeza berbanding masyarakat perladangan dan pertanian di kawasan luar bandar di negeri Pahang. Masyarakat bandar dan pinggiran bandar juga lebih terdedah dengan dasar kerajaan dan kesan urustadbir negara dan ekonomi global. Dalam berhadapan dengan kos sara hidup yang meningkat tinggi saban tahun umpamanya, masyarakat di kawasan ini lebih merasa kesannya berbanding mereka yang tinggal di luar bandar.

Akibat dari dinamik ini, pengundi bandar dan pinggiran bandar lebih termaklum (informed) dan kritis terhadap pemerintah. Hal ini dipermudahkan dengan kemajuan internet dan teknologi komunikasi (ICT) yang membolehkan mereka untuk berinteraksi, berkongsi maklumat dan berpartisipasi dalam dalam ruang digital (ruang umum baru), khasnya media sosial, dengan lebih aktif dan ekspresif di sebalik sekatan dan halangan yang dikenakan oleh pemerintah di ruang umum konvensional. Sokongan padu pengundi Cina terhadap DAP dan Pakatan Harapan pula, boleh digambar dengan kemahuan mereka yang mahukan 'negara idaman' yang berbeza berbanding model UMNO/BN yang semakin berasaskan kepada konservatisme Melayu-Islam dibawah pentadbiran Abdullah dan Najib (Shamsul, 1996).

Dari sudut model pengundian, terdapat ramai pengundi bandar dan pinggiran bandar yang membuat pilihan secara rasional sebelum membuang undi. Mereka tidak terlalu mengikat diri dengan mana-mana parti yang bertanding, sebalik mengubah-mengubah pilihan mereka berdasarkan kepentingan semasa mereka dan faedah yang boleh ditawarkan oleh pihak yang 
bertanding. Kegagalan berterusan BN dalam urustadbir ekonomi yang bersih dan berkesan umpamanya, menganjurkan ramai pengundi-pengundi di kawasan ini untuk menghukum BN sejak PRU 11 dan menyokong pembangkang dalam cubaan mereka untuk mengubah keadaan. Meskipun Bentong, Raub dan Temerloh adalah kawasan pinggiran bandar, tetapi kedekatan daerah-daaerah ini dengan Kuala Lumpur banyak memberi impak dalam proses pembandaran mereka, bukan sahaja dari sudut kemajuan ekonomi, tetapi juga dari sudut pembangunan politik. Disebabkan proses nyah-industrialisasi umpamanya, ramai golongan muda dari daerah-daerah ini bekerja dalam sektor moden di Kuala Lumpur, sekaligus membolehkan terdedah dengan dinamik ekonomi politik di metropolis itu. Faktor jarak yang dekat dengan pembinan lebuh raya yang maju, menyebabkan ramai juga daripada mereka untuk berulang-alik dari Kuala Lumpur dan tempat asal mereka di Pahang secara kerap. Hal ini secara perlahan-lahan merubah komplikasi politik di daerah mereka.

Jadual 1. Keputusan kerusi Parlimen Negeri Pahang PRU 14

\begin{tabular}{|c|c|c|c|c|c|c|c|c|c|c|}
\hline \multicolumn{4}{|c|}{$\begin{array}{c}\text { Kawasan Campuran } \\
(\text { etnik majoriti }<60 \%)\end{array}$} & \multicolumn{7}{|c|}{$\begin{array}{c}\text { Kawasan Majoriti Melayu } \\
(<60 \%)\end{array}$} \\
\hline Menang & Parlimen & Majoriti & Kawasan & Menang & Parlimen & Majoriti & Sandang & P2P & Supra-M & Kawasan \\
\hline BN-MIC & $\begin{array}{l}\text { C. } \\
\text { Highlands }\end{array}$ & 587 & LB & $\mathrm{BN}$ & Lipis & 13995 & $\mathrm{x}$ & $\mathrm{x}$ & $\mathrm{x}$ & LB \\
\hline PH-DAP & Raub & 3159 & PB & $\mathrm{BN}$ & Jerantut & 5608 & & $\mathrm{x}$ & $\mathrm{x}$ & LB \\
\hline PH-DAP & Bentong & 2030 & PB & PH-PKR & $\begin{array}{l}\text { Indera } \\
\text { Mahkota }\end{array}$ & 10950 & & & & B \\
\hline & & & & PH-PKR & Kuantan & 8111 & $\mathrm{x}$ & & & B \\
\hline & & & & $\mathrm{BN}$ & Paya Besar & 5742 & & $\mathrm{x}$ & $\mathrm{x}$ & PB \\
\hline & & & & $\mathrm{BN}$ & Pekan & 24859 & $\mathrm{x}$ & & $\mathrm{x}$ & PB \\
\hline & & & & $\mathrm{BN}$ & Maran & 3673 & $\mathrm{x}$ & $\mathrm{x}$ & $\mathrm{x}$ & LB \\
\hline & & & & $\mathrm{BN}$ & $\begin{array}{l}\text { Kuala } \\
\text { Krau }\end{array}$ & 2876 & $\mathrm{x}$ & $\mathrm{x}$ & $\mathrm{x}$ & LB \\
\hline & & & & PH-PAN & Temerloh & 1904 & & & & PB \\
\hline & & & & $\mathrm{BN}$ & Bera & 2311 & $\mathrm{x}$ & $\mathrm{x}$ & & LB \\
\hline & & & & $\mathrm{BN}$ & Rompin & 11395 & $\mathrm{x}$ & & $\mathrm{x}$ & LB \\
\hline Jumlah & 3 kerusi & & & 11 kerusi & & & 7 kerusi & 6 kerusi & 7 kerusi & \\
\hline
\end{tabular}

Sumber: dirujuk dan diubahsuai, The Star, https://election.thestar.com.my/pahang.html

Nota:

P2P: Jika persaingan Dua penjuru berlaku iaitu BN melawan gabungan PH-PAS.

Supra-M: Kawasan Supra-Majoriti Melayu dengan komposisi etnik itu melebihi 75 peratus

Sandang: Penyandang dipilih semula oleh pengundi

B: Kawasan Bandar

PB: Kawasan pinggiran bandar

LB: Kawasan luar bandar

Hal ini berbeza dengan di kawasan luar bandar di Pahang. Sistem ekonomi mereka kebanyakannya berasaskan pertanian dan perladangan, melibatkan pekerjaan berkemahiran dan bergaji rendah. Status kelas mereka ini menyebabkan akses mereka secara relatifnya terhad apabila dibanding dengan pengundi di kawasan bandar di Pahang. Ini telah menstrukturkan tiga ciri-ciri penting di kawasan luar bandar di Pahang. Pertama, adalah kebergantungan politik. Disebabkan kawasan ini secara relatifnya mundur, para penduduk kebanyakannya masih bergantung dengan pemimpin, khasnya dari parti pemerintah untuk mengubah keadaan mereka dan persekitarannya. Kedua, meskipun akses mereka terhadap teknologi moden adalah semakin meningkat, tetapi tahap keterbukaan dan partisipasi mereka adalah rendah jika dibandingkan dengan penduduk bandar. Kedua-dua ciri ini menyebabkan permainan politik pembangunan di kawasan luar bandar sebagai amalan yang berimpak tinggi dalam membentuk sokongan politik 
dan budaya kepatuhan di kalangan sesetengah mereka di kawasan luar bandar. Ketiga, kerana kesemua kawasan di luar bandar di Pahang, kecuali Cameron Highlands, adalah kawasan supramajoriti Melayu, permainan politik Melayu-Islam merupakan amalan yang umum. Untuk itu, ideologi Melayu-Islam di kalangan penduduk Melayu setempat di kawasan luar bandar di Pahang adalah lebih konservatif berbanding di kawasan yang lebih maju dan kawasan yang secara etniknya bercampur. Akibatnya, sesetengah pengundi di kawasan luar bandar di Pahang mengundi atas faktor identifikasi parti atau sosiologikal, berbanding atas pertimbangan yang $\mathrm{kritikal} / \mathrm{rasional}$.

Faktor regionalisme turut memerihalkan parti-parti yang bertanding mempunyai kekuatan yang berbeza-beza di kawasan yang berbeza. Dalam konteks persaingan tiga penjuru di Pahang, $\mathrm{BN}, \mathrm{PH}$ dan PAS adalah aktor utamanya. Di peringkat parlimen di negeri Pahang, sebagai mana yang telah dibincangkan, $\mathrm{PH}$ dari sudut ranking (kekuatan) merupakan pesaing utama di kawasan bandar dan pinggiran bandar. Gabungan parti BN pula adalah pesaing kedua di kawasan yang turut merupakan kerusi parlimen bercampur itu. PAS pula berperanan sebagai parti ketiga di kawasan ini, kerana sukar untuk mendapat sokongan dari etnik lain selain Melayu, atas keputusannya untuk bertanding secara bersendirian dalam PRU 14. Hal ini berlaku meskipun PAS turut melakukan strategi pragmatik, seperti meletakkan calon India di Parlimen Bentong. Tetapi BN merupakan pemain utama di kawasan luar bandar di Pahang, dengan menyapu bersih kesemua kawasan itu di peringkat parlimen Pahang.

Oleh kerana kesemua kawasan parlimen luar bandar di Pahang merupakan kawasan supramajoriti Melayu kecuali Cameron Highlands dan Bera, PAS muncul sebagai pencabar kedua berbanding PH. Dalam erti kata lain, pesaingan di luar bandar dimonopoli oleh BN dan PAS, manakala persaingan di bandar dan pinggiran bandar pula dikuasai oleh PH dan BN. Impak parti ketiga dalam persaingan parlimen di kesemua kawasan di Pahang adalah sangat terhad.

\section{Analisa pengundian di peringkat DUN PRU 14 Pahang}

Dinamik persaingan tiga penjuru di Pahang di peringkat DUN adalah agak berbeza jika dibandingkan dengan peringkat parlimen. Ini adalah kerana jumlah pengundinya yang lebih kecil, dan pengelompokan pengundi berasaskan etnik adalah lebih ketara. Di peringkat parlimen umpamanya (lihat Jadual 1), tiada kawasan majoriti Cina yang melebihi 60 peratus. Tetapi di peringkat DUN Pahang (lihat Jadual 2) terdapat dua DUN majoriti Cina. Kawasan DUN bercampur terdapat tujuh kerusi, enam daripadanya adalah di kawasan bandar dan pinggir bandar, serta satu di luar bandar. Bakinya, 33 kerusi DUN yang lain adalah kawasan majoriti Melayu dengan 24 daripadanya adalah kawasan supra-majoriti (dengan jumlah pengundi Melayu melebihi 75 peratus).

Hal ini membolehkan pengaruh parti yang lebih kecil, seperti PAS untuk lebih terserlah, khasnya di kawasan supra-majoriti Melayu. Ia juga menyebabkan persaingan pilihan raya di peringkat DUN di negeri Pahang lebih kompetitif dan dinamik berbanding di peringkat Parlimen. Faktor regionalisme sekali lagi terpakai dan begitu berhubungkait dengan dinamik komposisi etnik dalam menjelaskan pola pengundian. Regionalisme bukan sahaja wujud di antara kawasan parlimen di Pahang, tetapi juga di dalam (within/intra) sesuatu daaerah pilihan raya. Jika regionalisme di peringkat parlimen positif kepada $\mathrm{PH}$, tetapi regionalisme di peringkat DUN di Pahang, lebih memberi kelebihan kepada BN dan juga PAS kerana kewujudan banyak kerusi majoriti dan supra-majoriti Melayu. 
Di dalam lima kawasan Parlimen yang dimenangi oleh PH dalam PRU 14, terdapat 15 kawasan DUN secara keseluruhan. Namun PH hanya mampu menang tujuh kawasan DUN sahaja, iaitu kurang dari separuh. Hal ini tidak disebabkan oleh amalan pecah undi. Sebaliknya kerana dinamik intra-regionalisme di mana kesemua lapan kerusi yang gagal dimenangi oleh PH adalah disebabkan kerana enam daripadanya adalah kawasan supra-majoriti Melayu, dan dua lagi hampir mencapai status supra-majoriti Melayu iatu DUN Baserah (74 peratus) dan DUN Pelangai (70 peratus). Lapan kerusi majoriti Melayu di kawasan parlimen $\mathrm{PH}$, direbut oleh BN dan PAS secara khusus, dan PH hanya menjadi pemain yang ketiga. BN menang enam dari lapan kerusi itu, dan bakinya dikuasai oleh PAS.

Baki 27 lagi kerusi DUN Pahang, yang terletak di kawasan-kawasan Parlimen yang dimenangi oleh BN, didominasi oleh kawasan majoriti dan super-majoriti Melayu. Akibatnya PH sekali lagi lagi menjadi pesaing yang lemah dibandingkan dengan BN dan PAS. Di kawasan ini, PH hanya mampu 'mencuri' dua kerusi (Triang dan Tanah Rata), kerana kedua-dua kerusi itu mempunyai komposisi etnik Cina yang tinggi. Selebihnya (25 kerusi) adalah kawasan majoriti Melayu dan kebanyakannya adalah kawasan supra-majoriti.

Isu-isu semasa nampaknya begitu mengimpak corak pengundian di Pahang. Di kawasan bandar dan kawasan bercampur, pengalihan undi terhadap PH jelas berlaku. Kempen-kempen yang dilakukan oleh PH di peringkat nasional, negeri dan lokal, khasnya berkaitan dengan masalah urustadbir ekonomi pentadbiran Najib (isu 1MDB dan skandal RM2.6 bilion) dan kos sara hidup yang tinggi, di dalam ruang maya dan secara turun padang, berjaya membangkitkan sentimen anti-BN di kalangan ramai pengundi di kawasan ini. Hal ini diperkukuhkan pula dengan penyertaan Mahathir di dalam PH sebagai calon Perdana Menteri dan PPBM dalam menarik dan menyakinkan sokongan Melayu kepada PH.

PAS memenangi enam kerusi di kawasan majoriti Melayu di Pahang, dengan lima daripadanya adalah kawasan supra-majoriti Melayu. BN pula muncul sebagai pemenang terbesar di kawasan ini dengan memenangi 19 kerusi DUN dengan 13 daripadanya adalah kawasan supra-majoriti Melayu. Dari sudut kewilayahan, kekuatan PAS di Pahang secara umumnya terletak di kawasan majoriti Melayu yang agak terpencil dan relatifnya mundur di Pahang. Satu lagi hal yang agak penting adalah, dari sudut geografi beberapa kerusi DUN PAS Pahang juga letaknya bersebelahan atau berdekatan dengan negeri Terengganu, yang merupakan kawasan terkuat PAS selepas negeri Kelantan. Malah ramai pengundi di kawasan-kawasan ini berasal dari Terengganu. Hal ini mudah disedari dengan ketara kerana dialek Melayu Terengganu merupakan bahasa pertuturan yang utama. Sokongan pengundi kawasan ini, yang cenderung kepada PAS nampaknya dipengaruhi oleh proses sosiologikal yang panjang. Malah di DUN Damak, meskipun terdapat 58 peratus sahaja pengundi Melayu, PAS berjaya memenangi dengan majoriti dengan baik, kerana sokongan padu yang diberikan oleh majoriti besar Melayu di DUN itu. Keadaan struktural dan dinamika ini, untuk itu, telah menyebabkan pengaruh BN sebagai kerajaan negeri dan persekutuan pada ketika itu menjadi terhad di wilayah ini, kerana ia diisi oleh organisasi dan aktiviti agama yang dikuasai oleh PAS.

Corak pengundian anti-BN di Pahang ini jelas menunjukkan pengundi telah memilih parti kedua terkuat di kawasan pilihan raya di beberapa tempat. Di bandar dan kawasan bercampur, ramai yang memilih PH. Di beberapa kawasan luar bandar pula, PAS menjadi pilihan. Ini menerangkan penambahan enam kerusi DUN PAS dalam PRU 2018 (kesemuanya lapan kerusi) berbanding hanya dua sewaktu PRU 2013. Skandal yang terpalit kepada Najib dan BN khasnya dalam penyalahgunaan dana awam memberikan lebih kredibiliti kepada pemimpin PAS yang umumnya dibarisi oleh ahli agama yang dihormati oleh masyarakat setempat. Kesemua 25 kerusi 
yang dimenangi oleh $\mathrm{BN}$ adalah kawasan majoriti Melayu dengan kebanyakannya terletak di kawasan luar bandar. Hal ini, sebagaimana yang telah disebut, telah menolak PH untuk menjadi pemain yang ketiga. Sebaliknya pencabar utama BN di kawasan-kawasan ini adalah PAS. Namun berbeza dengan kawasan yang dikuasai PAS, jaringan, organisasi dan gerak kerja BN di kawasan ini adalah cukup mendalam dan meluas. Ia dimungkin dari penguasaan BN yang lama di kawasan-kawasan ini, di samping faktor penaungan, khasnya permainan politik pembangunan yang berkesan. Halangan struktural yang melanda masyarakat setempat di kawasan-kawasan DUN BN, sebagaimana kawasan Parlimen BN, menyebabkan kebergantungan yang tinggi di kalangan sesetengah pengundi, sekaligus menyalurkan sokongan yang tinggi terhadap parti pemerintah. Lama-kelamaan, faktor 'jasa' parti pemerintah menyebabkan sesetengah mereka mengidentifikasi diri dengan parti itu. Ini berikutan mereka sudah selesa dengan BN dan tidak menganggap masalah yang dibangkitkan oleh pembangkang sebagai isu besar. Dengan pelbagai bentuk penaungan dan 'perlindungan' yang telah diberikan kepada masyarakat khasnya orang Melayu (seperti subsidi kepada warga Felda dan kampung, kenaikan gaji penjawat awam, saguhati dan majlis makan anjuran $\mathrm{BN}$ ), ramai pengundi Melayu rasa lebih terjamin dengan pemerintahan BN berbanding parti pembangkang. Untuk itu, BN masih lagi parti yang popular di kalangan orang Melayu di Pahang, terutamanya di kawasan luar bandar, berbanding PH dan PAS. Oleh sebab ini, dinamik persaingan tiga penjuru di Pahang berbeza dengan di kebanyakan negeri-negeri lain di semenanjung di mana ia memberi kelebihan kepada BN untuk mengekalkan kerusi.

Namun terdapat juga dinamika pengundian di kawasan majoriti Melayu seperti di Jerantut dan Maran. Meskipun PAS menguasai kebanyakan kerusi DUN di kawasan ini, tetapi kedua-dua kawasan Parlimen itu dimenangi BN. Praktik pecah undi ini memperlihat kecenderungan pengundi setempat untuk mengekalkan penyandang yang berpengaruh meskipun menolak BN. Dalam hal ini, faktor calon dan clientalism mengatasi faktor parti. Kedua-dua calon adalah sosok besar di daerah masing-masing dengan kedudukan penting di peringkat persekutuan. Mereka juga telah memenangi pilihan raya sebanyak beberapa kali khasnya penyandang di parlimen Maran, memerihalkan jaringan penaungan dan sosial yang lama. Persaingan tiga penjuru di kawasan-kawasan ini juga telah menyebabkan perbezaan majoriti kecil berlaku di peringkat DUN masing-masing sekaligus turut membantu BN mempertahankan kedudukan di peringkat kerusi parlimen meskipun kehilangan beberapa kerusi DUN kepada PAS.

\section{Impak persaingan tiga penjuru di Pahang}

Perbincangan di dalam pola pengundian dan prestasi di kawasan Parliman dan DUN Pahang hanya memerihalkan separuh daripada realiti yang sebenar. Ini berikutan keputusan itu adalah sesuatu yang 'distrukturkan' (manufactured) berikutan dari manipulasi yang tinggi melalui sistem pilihan raya dan politik, berbanding persaingan yang adil dan bersih. Amalan gerrymandering (menggariskan sempadan pilihan raya untuk beri kelebihan kepada pemerintah) dan malapportionment (purata pengundi yang jauh berbeza di antara kawasan pro-pemerintah dan pro-pembangkang) adalah cukup ketara dalam PRU 14. 
Jadual 2. Kerusi Dewan Undangan Negeri Pahang

\begin{tabular}{|c|c|c|c|c|c|c|c|c|c|c|c|c|c|}
\hline \multicolumn{4}{|c|}{ Kawasan Campuran } & \multicolumn{6}{|c|}{ Kawasan Majoriti Melayu } & \multicolumn{4}{|c|}{ Kawasan Majoriti Cina } \\
\hline \begin{tabular}{|l|} 
Menang \\
\end{tabular} & Kawasan & Majoriti & Sandang & Menang & Kawasan & Majoriti & Sandang & P2P & $\begin{array}{l}\text { Supra- } \\
\text { M }\end{array}$ & Menang & Kawasan & Majoriti & Sandang \\
\hline PH-DAP & $\begin{array}{l}\text { Tanah } \\
\text { Rata }\end{array}$ & 3580 & & $\mathrm{BN}$ & Jelai & 3507 & $\mathrm{x}$ & & & $\begin{array}{l}\text { PH- } \\
\text { DAP }\end{array}$ & Tras & 9953 & \\
\hline PH-PKR & Teruntum & 7725 & $\mathrm{x}$ & $\mathrm{BN}$ & $\begin{array}{l}\text { Padang } \\
\text { Tengku }\end{array}$ & 1244 & $\mathrm{x}$ & $\mathrm{x}$ & $\mathrm{x}$ & $\begin{array}{l}\text { PH- } \\
\text { DAP }\end{array}$ & Triang & 6454 & 8 \\
\hline PH-DAP & Mentakab & 5829 & & $\begin{array}{l}\text { BN- } \\
\text { MCA }\end{array}$ & Cheka & 202 & & $\mathrm{x}$ & & & & & \\
\hline PH-DAP & Bilut & 3729 & & BN & Benta & 304 & $\mathrm{x}$ & $\mathrm{x}$ & & & & & \\
\hline PH-DAP & Ketari & 3710 & & $B N$ & $\begin{array}{l}\text { Batu } \\
\text { Talam }\end{array}$ & 4320 & $\mathrm{x}$ & & $\mathrm{x}$ & & & & \\
\hline PH-DAP & Sabai & 495 & $\mathrm{x}$ & BN & Dong & 3852 & $\mathrm{x}$ & & $\mathrm{x}$ & & & & \\
\hline PH-PKR & Semambu & 5511 & $\mathrm{x}$ & PAS & Tahan & 69 & $\mathrm{x}$ & & $\mathrm{x}$ & & & & \\
\hline & & & & PAS & Damak & 1456 & 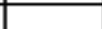 & & 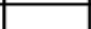 & & & & \\
\hline & & & & BN & $\begin{array}{l}\text { Pulau } \\
\text { Tawar }\end{array}$ & 587 & 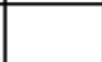 & 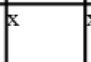 & $x$ & & & & \\
\hline & & & & PAS & Baserah & 1305 & & & & & & & \\
\hline & & & & PAS & \begin{tabular}{|l} 
Tanjung \\
Lumpur
\end{tabular} & 1339 & $\mathrm{x}$ & & $x$ & & & & \\
\hline & & & & BN & $\begin{array}{l}\text { Inderapur } \\
\text { a }\end{array}$ & 2165 & $\mathrm{x}$ & hampir & $\mathrm{x}$ & & & & \\
\hline & & & & BN & $\begin{array}{l}\text { Sg } \\
\text { Lembing }\end{array}$ & 1968 & $\mathrm{x}$ & $\mathrm{x}$ & $\mathrm{x}$ & & & & \\
\hline & & & & $B N$ & Lepar & 2779 & & $\mathrm{x}$ & $\mathrm{x}$ & & & & \\
\hline & & & & PAS & Panching & 135 & $\mathrm{x}$ & & $\mathrm{x}$ & & & & \\
\hline & & & & BN & $\begin{array}{l}\text { Pulau } \\
\text { Manis }\end{array}$ & 2334 & $\mathrm{x}$ & hampir & $\mathrm{x}$ & & & & \\
\hline & & & & BN & $\begin{array}{l}\text { Peramu } \\
\text { Jaya }\end{array}$ & 7182 & $\mathrm{x}$ & & $x$ & & & & \\
\hline & & & & BN & Bebar & 5720 & $\mathrm{x}$ & & - & & & & \\
\hline & & & & $\overline{B N}$ & Chini & 4622 & $\mathrm{x}$ & & $\mathrm{x}$ & & & & \\
\hline & & & & PAS & Luit & 272 & $\mathrm{x}$ & & $\mathrm{x}$ & & & & \\
\hline & & & & BN & $\begin{array}{l}\text { Kuala } \\
\text { Sentul }\end{array}$ & 2039 & $\mathrm{x}$ & & $x$ & & & & \\
\hline & & & & PAS & Chenor & 514 & $\mathrm{x}$ & & $\mathrm{x}$ & & & & \\
\hline & & & & BN & Jenderak & 1713 & $\mathrm{x}$ & hampir & & & & & \\
\hline & & & & $\overline{B N}$ & Kerdau & 1934 & $\mathrm{x}$ & hampir & $\mathrm{x}$ & & & & \\
\hline & & & & PAS & Jengka & 1813 & $\mathrm{x}$ & & $\mathrm{x}$ & & & & \\
\hline & & & & BN & Lanchang & 3725 & $x$ & & $x$ & & & & \\
\hline & & & & $\mathrm{BN}$ & $\begin{array}{l}\text { Kuala } \\
\text { Semantan }\end{array}$ & 474 & $\mathrm{x}$ & $\mathrm{x}$ & $\mathrm{x}$ & & & & \\
\hline & & & & $\mathrm{BN}$ & Pelangai & 2312 & $\mathrm{x}$ & hampir & & & & & \\
\hline & & & & BN & Guai & 3295 & $\mathrm{x}$ & & $\mathrm{x}$ & & & & \\
\hline & & & & BN & Kemayan & 4618 & $\mathrm{x}$ & & & & & & \\
\hline & & & & $\mathrm{BN}$ & $\begin{array}{l}\text { Bukit } \\
\text { Ibam }\end{array}$ & 2478 & & hampir & $\mathrm{x}$ & & & & \\
\hline & & & & $\mathrm{BN}$ & $\begin{array}{l}\text { Muadzam } \\
\text { Shah }\end{array}$ & 4840 & & & $x$ & & & & \\
\hline & & & & $\mathrm{BN}$ & Tioman & 1280 & $\mathrm{x}$ & $\mathrm{x}$ & $\mathrm{x}$ & & & & \\
\hline JUMLAH & 7 kerusi & 3 kerusi & & & \begin{tabular}{|l}
31 \\
kerusi
\end{tabular} & & \begin{tabular}{|l}
24 \\
kerusi
\end{tabular} & $\begin{array}{l}8 \\
\text { kerus }\end{array}$ & \begin{tabular}{|l|}
24 \\
kerusi
\end{tabular} & & 2 kerusi & & \\
\hline
\end{tabular}

Sumber: dirujuk dan diubahsuai, The Star, https://election.thestar.com.my/pahang.html

Nota:

P2P: Jika persaingan Dua penjuru berlaku iaitu BN melawan gabungan PH-PAS.

Supra-M: Kawasan Supra-Majoriti Melayu dengan komposisi etnik itu melebihi 75 peratus

Sandang: Penyandang dipilih semula oleh pengundi 
Parlimen Indera Mahkota, antara kubu kuat pembangkang di Pahang, umpamanya hanya mempunyai dua kawasan DUN. Sedangkan kawasan pro-parti pemerintah di Pahang umumnya mempunyai tiga kawasan DUN walaupun jumlah penduduknya adalah jauh lebih sedikit seperti di Parlimen Maran dan Kuala Krau. Malah di Parlimen Pekan, kubu kuat Perdana Menteri Najib Razak, diperuntukkan empat kawasan DUN.

Dari sudut purata pengundi pula, kawasan relatif pro-pembangkang seperti DUN di kawasan bandar dan kawasan bercampur, saiznya lebih besar berbanding kawasan relatif pro-pemerintah iaitu kawasan majoriti Melayu. Di Parlimen Raub contohnya, DUN Tras (kawasan majoriti Cina) mempunyai 28,912 pengundi berdaftar. Sedangkan dua DUN lain di daerah itu, Batu Talam dan Dong (antara kawasan supra-majoriti Melayu) masing-masing mempunyai 15,188 dan 13,623 sahaja. Hal ini membolehkan parti pemerintah 'mencuri' dua DUN dari Parlimen pro-PH di Raub dengan rekayasa kawasan pengundian berasaskan etnik. Ini selaras dengan kenyataan Pengerusi SPR Mohd Hashim Abdullah ketika itu, "we cannot simply divide an ethnic group in any particular area. As best as we can, we try to keep them together" (The Malay Mail, 2018).

Apabila dua amalan ini (gerrymandering dan malapportionment) digabungkan dengan strategi memecahkan parti dan undi parti lawan, parti pemerintah berjaya mengekalkan kedudukan di Pahang dengan agak selesa meskipun tidak lagi popular di negeri itu. Dalam PRU 14 BN Pahang buat pertama kali tewas dalam persaingan undi popular kepada pembangkang dengan hanya mendapat 41.6 peratus berbanding 54.8 peratus pada PRU 13. Parti pembangkang pula menguasai 58.1 peratus dalam PRU 14 di Pahang, dengan PH sebanyak 29.1 peratus dan PAS dengan 29 peratus populariti. Tetapi pemisahan undi pembangkang kerana perpecahan parti mereka telah menyebabkan BN muncul pemenang secara pluraliti di banyak kawasan DUN dan Parlimen Pahang.

Kawasan Parlimen pro-pembangkang Temerloh boleh menjelaskan hal ini. Meskipun dikuasai oleh $\mathrm{PH}$ di peringkat parlimen, dua dari tiga buah DUN di daerah Temerloh iaitu Lanchang dan Semantan, dimenangi oleh BN secara pluraliti. Dalam erti kata lain jika PH dan PAS bergabung dalam PRU 14, pembangkang boleh memenangi kedua-dua DUN itu dengan selesa. Dalam hal ini, dua lagi DUN pembangkang dirampas dengan mudah oleh parti pemerintah dengan strategi licik memecahkan undi pihak lawan.

Sebaliknya pertandingan tiga penjuru, sebagaimana yang telah hujahkan sebelum ini, membawa kesan yang berbeza dan bercampur-campur ke atas parti-parti yang bertanding disebabkan faktor kewilayahan. Dalam erti kata lain, keunikan regionalisme sosio-politik dan sosio-ekonomi Malaysia menyebabkan pengaruh parti-parti politik tidak seragam di kesemua kawasan. Perlawanan tiga penjuru di Pulau Pinang dan Selangor umpamanya, menguntung PH kerana di sana terdapat banya kawasan campuran, majoriti Cina dan banyak kawasan bandar serta pinggiran bandar. Di Terengganu dan Kelantan pula, persaingan tiga parti menguntungkan PAS kerana dinamik regionalisme lokal. PH pula merupakan parti yang rugi dalam persaingan seumpama ini di kedua-dua negeri itu dengan tidak memenangi sebarang kerusi parlimen di sana.

Sebaliknya dalam konteks dinamika regionalisme lokal di Pahang, persaingan tiga penjuru telah membolehkan BN untuk memenangi banyak kawasan Parlimen dan mempertahankan kedudukan sebagai kerajaan negeri, meskipun tewas dalam perebutan undi popular. Jika persaingan dua penjuru (P2P) berlaku dalam PRU 14 (lihat Jadual 1), melibatkan gabungan PH dan PAS, BN hanya akan memenangi dua dari empat belas kerusi parlimen di Pahang, iaitu Pekan dan Rompin. Malah di peringkat DUN, BN Pahang akan kehilangan kedudukan sebagai parti pemerintah di negeri itu jika bukan kerana perlawanan tiga penjuru. Gabungan parti PH dan PAS yang hanya menguasai 17 kerusi DUN melalui pertembungan tiga penjuru, boleh 
menguasai lapan lagi kerusi DUN (Lihat P2P di Jadual 2), membawa keseluruhan 25 dari 42 kerusi DUN jika perlawanan satu lawan satu berlangsung seperti PRU 13.

\section{Kesimpulan}

Dapatan dan perbincangan di dalam ini membawa implikasi kepada pemahaman kita dalam merefleksi realiti politik gabungan dalam masyarakat pluralisme di Malaysia di masa lepas, masa kini dan di masa yang akan datang. BN dan PAS kini telah mula menjalin kerjasama selepas PRU 14 dalam mengimbangi kekuatan PH sebagai kerajaan baharu dengan strategi persaingan satu lawan satu atau sistem dua parti gabungan. Dalam Pilihan Raya Kecil Parlimen Cameron Highlands di Pahang pada awal 2019 umpamanya, kerjasama BN dan PAS telah membuahkan hasil di mana ia berjaya menewaskan PH dengan majoriti yang lebih baik.

Tanpa kerjasama itu, kerusi parlimen itu boleh dirampas oleh $\mathrm{PH}$ dengan mudah. Oleh kerana sistem pilihan raya dan sempadannya telah direkayasa oleh BN sebelum PRU 14, kerjasama BN dan PAS pasca PRU 14 membawa kepada dinamisme baharu dalam kekuatan BN sebagai pembangkang baharu. Kerajaan PH dijangka akan merespon terhadap perkembangan ini, secara pragmatik (dengan merekrut (co-opt) perwakilan perundangan $\mathrm{BN}$ ) dan mungkin juga secara prosedural di masa hadapan dengan merubah sempadan pilihan raya atau memperkenalkan sistem pilihan raya yang baharu. Langkah yang kedua itu adalah lebih diperlukan bagi mewujudkan sistem pilihan raya yang lebih reflektif dengan pilihan umum. Ia juga selaras dengan agenda reformasi institusi kerajaan dalam membentuk struktur politik yang lebih adil dan demokratik di Malaysia.

\section{Penghargaan:}

Penyelidikan dan penulisan artikel ini dibiayai oleh Geran Galakan Penyelidik Muda Universiti Kebangsaan Malaysia (GGPM-2018-022).

\section{Rujukan}

Abdul Razak Raaff. (2018). 825,636 layak mengundi di Pahang. Harian Metro. 13 April. Retrieved from https://www.hmetro.com.my/mutakhir/2018/04/330280/825636-layakmengundi-di-pahang

Brownlee, J. (2007). Authoritarianism in an Age of Democratization. Cambridge: Cambridge University Press.

Campbell, A., Converse, P.E., Miller, W.E., \& Stokes, D.E. (1960). The American Voter. Oxford: John Wiley.

Compton, Robert W. (2000). East Asian Democratization: Impact of globalization, culture, and economy. Wesport: Praeger.

Department of Information. (2015). Population by States and Ethnic Group. Ministry of Communications and Multimedia, Malaysia.

EC chief admits racial redelineation, says ethnic groups can't be split. (2018, March 29). The Malay Mail. Retrieved from https://www.malaymail.com/s/1610117/ec-chief-admitsracial-redelineation-says-ethnic-groups-cant-be-split 
Fiorina, M.P. (1981). Retrospective voting in American national elections. New Haven: Yale University Press.

Lazarsfeld, P.F., Berelson, B., \& Gaudet, H. (1944). The people's choice. Oxford: Duell, Sloan \& Pearce.

López, Juan J. (2002). Democracy Delayed: The Case of Castro's Cuba. Baltimore: Johns Hopkins University Press.

Muhamad Nadzri Mohamed Noor. (2018). The 14th General Election, the Fall of Barisan Nasional, and Political Development in Malaysia, 1957-2018. Journal of Current Southeast Asian Affairs, 37(3): 139-171.

Muhamad Nadzri Mohamed Noor \& Jamaie Hamil. (2018). Politik, Pengundi dan Faktor Melayu/Bumiputera: Analisis Terhadap Kegagalan Barisan Nasional dalam PRU 2018. Journal of History, Politics and Strategic Studies (JEBAT), 45(2): 386-408.

Ostwald, K., Schuler, P. and Chong, J.M. (2018). Triple Duel: the Impact of Coalition Fragmentation and Three-Corner fights on the 2018 Malaysian Election. Journal of Current Southeast Asian Affairs, 37(3): 31-55.

Shamsul A.B. (1996). Nations-of-intent in Malaysia. In S. Tønnesson, \& H., Hans Antlöv, Asian Forms of the Nation (pp. 323-347). Hove: Psychology Press.

Shedler, A. (2002). Election without democracy: The menu of manipulation. Journal of Democracy, 13(2): 36-50.

The Star Online. (2018). GE 14. Retrieved from https://election.thestar.com.my/pahang.html 